\title{
Self-Confrontations: ,Socrates", Wittgenstein and the Reference to What Cannot be Known
}

\author{
CHRISTIANE THOMPSON, JAMES THOMPSON
}

Education and Bildung are not exhausted in the expansion of knowledge, but rather they are closely connected with the dignity and the legitimation of knowledge as well as with the question of how this knowledge is meaningful for one's own existence. One can say at least that this statement represents one of the oldest leitmotifs of the Western pedagogical tradition. In this context it is held that human beings are not determinate regarding what or who they are. Rather, it is the challenge and responsibility of human beings to determine and to critically reflect all the relevant issues for one's own life as well as for the life of the community. Even the Aristotelian description of human being as zoon logon echon, i.e., as talking and thinking living being, thematizes this idea and directs attention toward these questions of human existence: In what framework is this existence philosophically graspable, and how does it become the topic of pedagogical reflection?

These questions have been framed all too hastily into a humanistic setting, thereby suggesting the feasibility and determinability of a humane human being. In contrast to the highly influential self-elevation of human self-realization in the (pedagogical) modern era (cf. Ballauff 2004, Meyer-Drawe 1998), one can refer to the beginning of pedagogy and philosophy in ancient Greece. In ancient Greece the question of how to lead one's own life was conceived as a personal as well as political problem that required considerable attention, specifically with respect to the relevant knowledge and how, if at all, this knowledge can be acquired. Socrates and his elenchus, as portrayed in the Platonic dialogues, provides the most salient example for our attention. With his method Socrates was able to lead his interlocutors to the point where the limits of knowledge central to both one's own life and that of the polis, i.e., knowledge of the aretai, became apparent. 
In the German educational-philosophical discourse Wolfgang Fischer has critically dealt with the skeptical and revisionist move of the Socratic elenchus. ${ }^{1}$ In particular, Fischer worked out to what extent Socratic ignorance and the immanent problematization of world views are pedagogically significant. According to Fischer, the pedagogical relevance of ignorance is captured in the insight that ,no one - be it not yet, be it (n)ever - has answered in a conclusive manner the fundamental questions in the mode of knowledge: Reclaimed knowledge is only supposed knowledge; the pillars that warrant its truth lie through the teeth. Then, it is not good to leave people in the frenzy of their knowledge, for within this state they undermine and block that from which knowledge and the desire for knowledge originates: i.e. questioning and thinking" (Fischer 2004: 130, our transl.). In Fischer's view, the pedagogical significance of the Socratic elenchus lies in pointing out the limits of knowledge, and thereby thrusting people back upon their own thinking and questioning.

Even today the question of the pedagogical significance of the Socratic elenchus has not faded away. How do knowledge and ignorance at all relate? Is there a pedagogical productivity to ignorance? Does a non-affirmative attitude which constantly questions how we approach thinking lie at its core? In relation to Fischer's engagement with Socrates - and also with his own skepticaltranscendental critical approach - the question of whether or not the approach of skeptical pedagogy can be legitimated has unfortunately been limited to the education-philosophical horizon of ,destructivity“ and „,constructivity“. Doubt has been cast upon the "real-world feasibility“ of a pedagogy that claims to act upon the denial of that which is false (cf. recently Reichenbach 2007: 211). Furthermore, a marginalization of fundamental, theoretical reflection has taken place in favor of an efficiency-oriented approach to education.

In our judgment, it is disappointing that the educational(-philosophical) discourse has accepted the categories „destructive“ and „,constructive“ without having dealt further with the question regarding the relationship between knowledge and ignorance. The model of pedagogical action has already decided on the standards of pedagogical quality. The question regarding the pedagogical productivity of this relation as well as the question concerning the possibility of it being the object of pedagogical reflection fades into the background.

By way of example, we are interested in the way Socrates is able to make his interlocutors aware of their own existence and to illustrate that one's own

1 Cf. Fischer 1997: 83ff. and even more comprehensive in Fischer 2004: 94ff. Fischer's own skeptic-transcendental critical approach (1989) bears strong connections to the Socratic elenchus (cf. Ruhloff 1999a, 1999b and Schönherr 2003). We take the opportunity here to remind the reader of the highly analytical and stringent advancements of Wolfgang Fischer (1928-1998). 
selfhood is attached to the question of the virtues - to make them take care of their own lives. Beginning with Kierkegaard (who drew liberally from Socrates), this highly important problem has been discussed as a problem of ,indirect communication". Kierkegaard employs this method because he believes a direct approach to the reader fails when what is to be discussed focuses on the existential relations of the one addressed. The indirect method leads the reader to him- or herself and allows the reader to comprehend that, within the framework of the medium itself, it is the reader's existence that is at stake.

In this essay we intend to expose the relationship between the limits of knowledge and its meaning for one's own self. We will trace this relationship first with regard to the Socratic elenchus in Plato's dialogue Charmides, and from there move over to Ludwig Wittgenstein's earlier work, the Tractatus logico-philosophicus. Both of these texts offer themselves for our approach because they are modelled as a ,process of discovery“ (Conant 1997). In this process the limits of knowledge quickly become apparent in the personal relationship regarding the addressee: The meaning of these two texts can only be grasped beyond their explicit givenness. ${ }^{2}$

Taking the oracle of Delphi as our point of departure, we will first analyze the occurrence of the aporia for the different dialogue participants in the final part of Charmides, and then attempt to show how the determination of knowledge is breached. In the second part, we will examine Wittgenstein's strategy of confronting the readers with the limits of representation by letting them walk the path of representation. In the third part of the paper we will make some concluding remarks regarding the relationship of Bildung and ignorance.

\section{The Socratic elenchus as Pedagogical Practice: Charmides and the Visitation of the Self}

According to Socrates, the Oracle of Delphi's pronouncement that no man was wiser than he represents an important point of departure for testing and refuting his interlocutors. Confused by this decree, Socrates sets out to question reputedly wise men in order to find someone wiser than himself (see Apol. 21b and Fischer 2004: 87-88). Socrates proceeds very much in accordance with the Oracle because its cryptic assertions represented the opportunity and the point of departure for self-reflection and self-examination. Accordingly, the cult site of Delphi - dedicated to the God Apollo - was associated with the demand to „know thyself“. And „,to know oneself“ pre-domi-

2 Peperzak (1998) has resituated philosophical work, the legein ti kata tinos, in the dialogical situation and clarified the constitutive function of interaction for philosophy. We do not agree with Frost (1999) that Plato's dialogues cannot stay true toward the dialogue. 
nantly meant to be in full awareness of humans' limited position regarding knowledge in comparison to the gods. That the Oracle's prophecy does not provide specific information, but rather constitutes a riddle ${ }^{3}$ to which the recipient of the assertion must dedicate herself, accords with a fragment from the pre-Socratic thinker Heraclitus: „The Lord of the Oracle in Delphi neither speaks out nor conceals the matters but gives indications" (DK 22 B93, our transl.). ${ }^{4}$ For those seeking its advice, the Oracle's insight represents the beginning of an engagement with oneself.

In his studies of the ancient world, Foucault has demonstrated that the oracle's call to self-knowledge was commonly too epistemologically and theoretically conceived. The appeal to know thyself, according to Foucault, is tied more closely to the maxim: to search and become more concerned with oneself (see Foucault 1993: 28f.). ${ }^{5}$ It is precisely this dealing with oneself, the epimeleia heautou, which moves Socrates to take the Oracle's pronouncement as his point of departure both to reconsider his own existence and as inspiration to get others to care about their own souls (Apol. 29e).

In order to analyze how Socrates attempts to realize this pronouncement as well as how self-concern and the limits of knowledge are interwoven, it is helpful to take a closer look at Plato's dialogue Charmides. This dialogue depicts Socrates as a forceful skeptic. ${ }^{6}$ Here, self-investigation and the question concerning the limits of knowledge represent the main points because the dialogue is primarily concerned with ,sophrosyne“, a term that is inadequately captured by the concepts „temperance“ and „moderation“. ,Sophrosyne“ is traceable to the concept ,phren" ${ }^{7}$, which in turn is the origin of the word cluster around ,phronesis". A person who is ,sophron" is in a position to do more than just arrange and judge the situation-related state of affairs. This perspicuous insight or structuring estimation implies an obligation to understand both oneself and one's own actions.

3 The prophecies of the oracle in Delphi have frequently been accompanied with the expression „tauta phrazeste“ (,Think these issues over!"). The Greeks have been conscious regarding the challenges the riddle imposes on them.

4 The Greek original for indication reads ,semainein“. It means to be a sign or suggestive of something.

5 This is in turn the point of departure for Foucault's engagement with the ancient world.

6 Wolfgang Fischer has placed this dialogue in the centre of his attention in order to analyse the Socratic negation of knowledge: cf. Fischer 2004: 96ff. There has been a constant discussion whether the Socrates of the early Platonic dialogues is an authentic presentation of the historical Socrates. Fischer (2004: 29-82) has dealt extensively with this question. Cf. also Penner 1992.

7 „Phren“ literally means diaphragm or phrenic. According to the Greek view, it is the dividing line in the body that is responsible for keeping everything in proper place and particularly, to separate the higher from the lower organs. 
The dialogue follows Socrates who, upon returning home from the war, meets the young and handsome Charmides. Critias (Charmides' uncle) suggests to Socrates that Charmides is exceptionally clever and temperate. As a „treatment“ intended to alleviate the headache Charmides currently suffers from, Socrates proposes a discussion concerning „temperance“. Charmides” traditional attempts to answer the question, e.g., temperance is a state of calm, a critical stance or even a shyness, are analyzed and then refuted. As the dialogue progresses, Critias adopts the position that „temperance“ means „to do one's own work to attain the good" (to ta heautou prattein). Subsequent to the conceptual approaches that Critias continues to offer, a discussion arises whether sophrosyne can be understood in terms of a form of knowledge that captures the relation to the subject of knowledge or ignorance, i.e., to the person who does (not) know. At this point in the dialogue, it appears as if Critias is going to prevail in that he resists Socrates' challenging questions, for these seem more focused on refuting him, Critias, than on getting to the bottom of temperance. However, because Critias cannot offer a plausible account of a knowledge concerning that which one (does not) know the dialogue results in an aporetic conclusion.

However, the concept of aporia does not satisfactorily characterize the situation at the end of the dialogue. In other words, the unresolved situation should not be reduced to the insight that after the various unsuccessful attempts (to determine what ,temperance“ is) no reliable determination is possible and that it appears necessary to once again meet and discuss. Toward the end of the dialogue, the reader's attention is directed toward the interlocutors and specifically how they partake in the dialogue with Socrates. Charmides utters, at the end of the dialogue,

I am sure that I do not know, Socrates, whether I have or have not this gift of wisdom and temperance; for how can I know whether I have a thing, of which even you and Critias are, as you say, unable to discover the nature? - Yet, I do not quite believe you, and I am sure, Socrates, that I do need the charm, and as far as I am concerned, I shall be willing to be charmed by you daily, until you say that I have had enough (Charm. 176a-b, transl. Jowett).

In this quotation, the participants of the dialogue are presented as being equally ignorant regarding the question of temperance. However, from the quotation we can conclude that Charmides is suspicious of Socrates. There is something else - some knowledge regarding temperance. It is interesting that Socrates is willing to meet again with Charmides even though he himself - in the middle of the dialogue - vigorously insisted his own ignorance regarding the discussed matter (Charm. 165c). The dialogue gives a hint that there is more to say about the matter than that the question regarding temperance re- 
mains unanswered. With his remark Charmides shifts the view towards the dialogue participants' relation to temperance. The reader wonders how the three interlocutors' relation to the discussed matter can be described and in what way their relationships are relevant for the discussed matter itself.

The participants of the dialogue comport themselves very differently toward the challenge of what there is to say about temperance. Critias is a dialogue partner who is familiar with the Sophistic ,education'. He presents himself as someone who has sufficiently dealt with the aretai and with sophrosyne, in particular. Yet, the reader notices that Critias does not enter into the dialogue with a firm position that is well thought out. Rather, he deliberately introduces word distinctions that are not germane. He refers to traditional views and shifts from one opinion to another. Utilizing these techniques, Critias rather seems to withdraw from Socrates' questions than to confront them. Critias treats the answers that he gives as something that does not have anything to do with his own life. Even though Critias is eager to enter into the dialogue, he does not show any interest by the end of the dialogue to meet again in order to continue the discussion. Rather, he seems to be relieved that the focus of the dialogue moves back to Charmides.

Charmides takes up a different relation to the discussed matter. The above mentioned quotation shows that he is in a different position than at the beginning of the dispute. Charmides retreats from the decision of whether or not he is in possession of temperance because of the insight of how difficult it is to determine the criteria for such a proposition. Yet, he requires Socrates to meet again with him. According to Charmides, there is something that Socrates has to offer but it is unclear what it is: „I am not fully convinced of your ignorance,“ Charmides says, insisting that, „I am sure that I need to be charmed by you“ (Charm. 176b). „Charmed“" is the translation of „epodes/epaidein“" which means to be overwhelmed by a song or to be enchanted. Socrates' harsh and relentless elenchtic practice is described with a term that is rather associated with the sophists, i.e. their attempt to flatter their audience by their speeches, or with the storytellers who deliberately combine themes without delving into their true state of nature (mythologein). Without engaging the criticism of the sophistic movement and of poetry found in the Platonic opera, we wonder whether the term ,enchantment" precisely takes up the borders of knowledge experienced in the discussion on temperance between Socrates, Charmides, and Critias. This understanding would mean that the Socratic elenchus operates on the very impossibility to put in explicit terms ${ }^{8}$ what temperance is about.

8 Wolfgang Wieland (1999) has attempted to grasp these limits of the explicit by distinguishing propositional from non-propositional forms of knowledge. We agree with Wieland that the borders of what can be made explicit are decisive. The distinction of propositional versus non-propositional knowledge gives the 
In view of this impossibility, the meaning of Socrates' engagement with the dialogue participants changes: The elenchus does not only invalidate the definitions of temperance that were given by Charmides and Critias. It shows that the constitutive relationship between the aretai and the (health of the) soul cannot be put in explicit terms or arguments. The terminology of knowledge is improper to grasp this relationship. Yet, the experience of its inadequacy indicates that which goes beyond the order of knowledge.

Put in these terms, Socrates' elenchus amounts to a pedagogically initiated visitation of the self. According to Socrates, it is - from the very beginning of the dialogue - out of the question that the discussion on temperance needs to relate in a specific fashion to the people participating. Correspondingly, Socrates requests Charmides to examine himself (skeptomai) and formulate his answers on the grounds of his self-inspection. Socrates' questions point toward that which cannot be phrased in the language of knowledge and arguments. The ignorance (Nicht-Wissen) that we encounter here is not of the same kind as, e.g., failing to know what the abbreviation „UDHR“ stands for. This kind of ignorance denotes the necessary and inevitable reference to our own existence, a reference that cannot be identified clearly but shifts along with our attempts to grasp it.

However, being a necessary and inevitable reference, ignorance does not become a reassuring force in everyday life. Rather, the visitation of the self leads to a bracketing of the self and its pretences of knowledge. One could speak of an active and responsive ignorance ${ }^{9}-$ a determining force that itself cannot be determined. Correspondingly, Charmides sees himself as dependent on future discussions with Socrates: A further enchantment that might allow him to experience the borders of knowledge. This track is the philosophical life - as a matter of fact: it is the track of temperance itself without being able to determine how far along one is on this very track. ${ }^{10}$ The ,care of the self ${ }^{6}$ might bring about eudaimonia (happiness) - however, the human perspective on this issue proves again to be limited.

entire Platonic opera a different appearance - from the doctrine of the forms to Plato's extensive criticism of writing in the Phaedrus to his rigid criticism of the Sophists. However, even though Wieland's approach promises undoubtedly further insights, we will refrain from the distinction of (non-)propositional knowledge in the present context. The reason is twofold: First, we think that the terminology is not helpful for further investigating into the limits of knowledge, and secondly we are not so much worried about Plato but about the Socratic elenchtic method (as presented by Plato).

9 This notion contradicts the everyday understanding of ,ignorance“ that is mostly associated with forms of indifference and a dull apathy.

10 The attachment to the aretai is founded by an engagement with them. However, this happens in a way which does not nullify the difference between man and god. Alfred Schäfer (2005) has engaged in a similar systematic figure by analyzing the Socratic elenchus as initiation practice. 
Critias - in contrast to Charmides - leaves the dialogue scene without having experienced what ignorance is about. We can conclude from his example in Charmides that Socrates' method of indirect communication is not in and of itself successful. The pedagogical relationship is fragile. It withdraws from arrangement and plan and remains strictly oriented toward the addressee. ${ }^{11}$ Socrates' elenchus is a matter of involvement and the ones who are not drawn into this sphere remain outside and embarrassed because of the disclosure of ignorance. The reader of Plato's Charmides is aware that Critias will become one of the forty tyrants and thereby show that he last lost the question of temperance.

\section{Tackling the Limits of Knowledge and Representation: Wittgenstein's Tractatus}

While it is broadly conceded that the interaction between Socrates and his interlocutors can be viewed in pedagogical terms, the same cannot be said of Wittgenstein's philosophical works. Only recently has a more prominent systematic-pedagogical reading of Wittgenstein been undertaken, albeit with a pronounced emphasis being placed on his Philosophical Investigations. ${ }^{12}$ Given the fact that Wittgenstein has dealt intensively with the dimensions of knowledge and ignorance, certainty and uncertainty, and that he was always concerned with our relationship to the world, the delayed response within the pedagogical reception is difficult to understand. ${ }^{13}$

For the education-theoretical significance of ignorance we turn to Wittgenstein's early work: the Tractatus logico-philosophicus. After a short overview of this approachable yet inscrutable work, we will look at the difference defining it: the difference between the sphere of representation of states-ofaffairs as well as facts and the sphere of that which exceeds the limits of representation - a sphere which is yet existentially meaningful. From this point,

11 This strict reference to the addressee allows us to explain why this practice must appear as disproportional toward outside viewers of the dialogue.

12 We only want to point briefly toward the most important publications in this area: Smeyers/Marshall 1995; (in reference to Wolfgang Fischer) Dörpinghaus 2003; Ramaekers 2003; Platzer 2007; Peters/Burbules/Smeyers 2008. These publications deal with the role of skepticism for educational phenomena (e.g. learning) and educational research. However, especially the more recent publications also deal with the educational dimension in the philosophical work of Wittgenstein. The Anglo-American discourse has in some respects a stronger tradition in reflecting the significance of Wittgenstein's thoughts for educational research.

13 In the Anglo-American philosophical reception, the idea that Wittgenstein's thought (in both his early and later texts) is therapeutic in nature is important; a description he himself later used to characterize his approach. See such authors as Stanley Cavell, J.C. Edwards, and various New Wittgenstein interpreters. 
we then ask about the meaning this difference entails in the reader's relationship to herself.

Wittgenstein's Tractatus logico-philosophicus certainly belongs to the more enigmatic texts of philosophy. In a work not even 80 pages long, the author claims to more or less have solved the problems of philosophy. The structure of the text is made up of propositions accompanied by an unusual and intricate numbering system, ${ }^{14}$ both of which suggest logical argumentation and rigidness of sense. Complicating matters, the first section of the book appears to consist of a set of concluding statements beginning with a statement which rhymes in the original German „The world is all that is the case“" (TLP \#1). And while the Preface does provide the reader with a clue as to the point of the text, the message is more than cryptic: „What can be said at all can be said clearly, and what we cannot talk about we must pass over in silence“" (TLP, Preface).

For anyone acquainted with Wittgenstein's earlier work, these two statements will certainly sound familiar. However, what they entail is much more complicated and difficult to explain; for the statements themselves do not remain, strictly speaking, in the realm of expression and language: They presume a perspective beyond what is accessible to us. Thus, the first glance at the Tractatus already shows that the text does not remain in the rigid realm of representation. It is pointing toward something else - something that is perhaps best described utilizing the distinction of the „sayable“ and the ,unsayable“" or ,saying“ and ,showing“.

Wittgenstein was clearly aware that the limits of representation cannot be grasped from within representation. In an often cited letter to Ludwig von Ficker, he claims that the more important part of his work lies in that which is not written, i.e. the ethical part (Wittgenstein, 1980: 96). In this remark, Wittgenstein confirms a perspective that exceeds the realm of representation. And even more important: The significance of the Tractatus for the reader precisely lies in that which is not said in the book. Contrary to what appears to be a text focused on epistemological issues of language and logic, the reader is confronted with a book that is supposed to complement a book that cannot be written. In the following, we will first describe how the distinction of ,saying“"vs. ,showing“" unfolds within the text.

From the outset, the reader of the Tractatus is put on the path of logical argumentation. Wittgenstein presents an intricate system of propositions that brings the reader into contact with the logical categories that determine the representation of the world. Two aspects are worthy of note here. First of all,

14 Each proposition is given a number that not only designates that particular proposition, but also the proposition to which it refers. For example: 2, 2.01, $2.011,2.012,2.0121$ etc. The majority of the seven ,main propositions ${ }^{6} 1-7$ include this fairly complex substructure. 
the rigidity and solidity of structure needs to be pointed out: By reducing his thoughts to a network of propositions, Wittgenstein narrows the path of thought that the reader may tread while reading the Tractatus. Moving from the main proposition to definite explanatory propositions, the reader is not provided with a further reaching context or theoretical framework. Rather, she is bound to a pure logical structure constituted by the numbering system, on the one hand, and to a defining semantics as well as mathematical notations, on the other.

Secondly, the propositions offered in the Tractatus provoke an involvement on the reader's part by giving herself over to the attempt to understand the logical structure of language and the world. Entering the Tractatus, the reader is obligated to leave behind the indistinctness and confusion of everyday speech. The reader is, in other words, admonished to break with her everyday views and commit herself to a perspective of analysis and clarification. This perspective, however, affects her view regarding herself and the world; for the Tractatus is precisely dealing with language and thought - with reality. From here we can conclude that the reader will invest herself in comprehending and understanding what the Tractatus has to offer. In a way very similar to Kant in his Critique of Pure Reason, the reader of the Tractatus is committed to a critical delineation regarding what it makes sense to say.

Both aspects - the rigidity of logical structure as well as the reader's commitment to the clarifying analysis - need to be stressed explicitly in order to judge adequately the ,turning point' that the reader encounters toward the end of the book. Here, the reliable logical ground is pulled - like a rug - out from under the reader's feet. The entire Tractatus builds from the idea that in the light of logical achievement, language is related to statements and states-ofaffairs (which in turn reflect the constituents of the world). However, the Tractatus itself precisely does not remain true to the assignment of critical and regulating intervention because it consists of statements about the world, about the nature of representation and their logical form. This task is one that language (in light of a rigid theory of representation) is incapable of achieving. By performing the analysis (in the way it is required to be performed according to Wittgenstein), the entire analytical endeavor comes in jeopardy of self-refutation.

Yet, it is the very experience of inadequacy and failure that allows the reader to glimpse the limits of knowledge and her ability to know. In this respect, the text and its structure serve a purpose beyond the actual content of the statements. In the very moment that the primary goal of logical intervention fails, the Tractatus opens the realm toward that which escapes representation. The success of Wittgenstein's endeavor lies, so to speak, in the possibility of bringing about the failure of the endeavor. The success lies beyond the ,inner limit“ that his insight into representation allows us to trace out. Put in 
different terms, the insights gained are neither representable nor directly expressible - they can only be shown.

When we actually reflect upon what is expressible or sensical, according to Wittgenstein, one is struck by just how narrow this field of language is compared to the variety of propositions we actually use. In \#4.11, Wittgenstein affirms that the sensical realm is synonymous with that of the natural sciences. Notably, he excludes philosophy from the (natural) sciences, and thus from treating the sensical realm. This is to say that all ethical, aesthetic, and metaphysical statements do not belong to the sensical realm. According to Wittgenstein, they only mimic ${ }^{15}$ the structure of sensical statements, because they utilize the structural form of facts or states-of-affairs.

However, in light of that which exceeds representation, metaphysical, ethical, and aesthetic statements are analogously not denied their meaning outright: Wittgenstein distinguishes between mere nonsense and a significant nonsense or nonsense that points toward something more (cf. TLP \#6.522 and 6.54). On the one hand, they are devaluated because they can neither be the object of representation nor the object of knowledge. On the other hand, they become highly esteemed because of their constitutive role for the realm of representation. This role can be described as a negative critical function very similar to the significance of the thing-in-itself in Kant's First Critique. For Wittgenstein it means a liminal concept that marks the limits of possible knowledge: the limits of representation.

Over and beyond the critical delineating function of statements that exceed the realm of representation, Wittgenstein ascribes a positive significance to the nonsensical- and perhaps this thought is also not unlike Kant's point of view in the Critique of Pure Reason. Wittgenstein claims the inability to remain within the boundaries of representation. He makes this claim not only because something like a boundary or a limit seems to be unavailable within the limit (see above). Wittgenstein sees the subject itself - it is the subject through which good and evil enter world (cf. \#5.632) - as the limit of representation. We interpret the liminality of the subject, its relations to what is ethical, metaphysical, etc. as a decentering, and yet grounding move with respect to the world. What does this mean with respect to the reader's relationship toward the world as well as to herself?

According to our reading, this question is essential to the Tractatus, because we conceive of it as a primarily ethical book. ${ }^{16}$ The Tractatus goes beyond the epistemological questions of what can be the object of representation

15 Fahrenbach (1997) has analyzed more thoroughly this misuse of language.

16 As we have already seen, Wittgenstein points out the ethical dimension of the Tractatus himself. However, in the present context, the term ,ethical“ implies more than a reference to ethical statements. It means that in the present context the relation between Wittgenstein and the reader is substantial. 
and of how our language is structured with respect to the world. By touching on the question how we can relate to world and ourselves, Wittgenstein moves the focus toward how we can situate ourselves at all with respect to the world. And here, we are confronted with the fact that neither our issues can be part of the representational realm (and therefore they will always lack a final logical clarification or reasoning) nor can we ourselves situate ourselves within given representational contexts. We are always in touch with the limits (as being those very limits). Yet, we are also beyond representation. It is this unwritten or invisible part of the Tractatus (cf. J. Thompson 2008) that gives the book a „mystical end“. „End“ is, here, to be taken in a literal sense, on the one hand, and in the sense of ,meaning“ or ",purpose“, on the other. ${ }^{17}$

It is by the end of the book that the reader may realize that this book, strictly speaking, is a work of nonsense (TLP \#6.54). In the last sections of the book, the reader is confronted with what appear to be interjections disrupting the previous discussions of language and world. These statements can be read as the outcome of what had gone on before. In the second to last passage of the text Wittgenstein equates the propositions to a ladder that once climbed must be discarded; for the ladder is illusory, and therefore can provide no real ground or stability from which to move outside the world or gain reliable insights regarding ourselves or our ethical questions.

How is the Tractatus supposed to alter the reader's relationship to the world as well as to herself? If Wittgenstein declares philosophy a nonsensical program, how can the reader take a stance at all? According to Wittgenstein, it is necessary to engage in logical clarification and thus, engage in drawing boundaries (while at the same time being aware that it is impossible to stay within the boundaries). However, the approach remains indirect: From Wittgenstein's point of view, the reader should not engage in and generate nonsensical (philosophical) propositions (as it is done here). Philosophy, then, is the permanent critical activity of drawing limits (TLP \#4.112) and by doing so: 1) preserving that which exceeds representation and 2) soothing the frustration of being unable to get hold of that which actually matters with respect to the meaning of life.

At first glance Wittgenstein's interpretation of philosophy might appear as a philosophical program of bewilderment, a program that in view of the existence of fundamental boundaries obligates the philosopher to practice silence. Logical analysis and the self-investment into a "life of knowledge“ (Wittgenstein 1969: 81e) seem to be a successful way to come to terms with the intrusion of ethical issues in our lives. However, this „coming to terms“ must not be interpreted as an exclusion of the ethical, metaphysical, and

17 This interpretation goes, in some sense, too far: In this article, we have put in terms, what, according to the Tractatus, can only be a matter of showing. 
mystical. Rather, philosophy can be interpreted as a therapeutic activity, i.e. an activity that coerces us to face our liminality and make it present to us. The most problematic feature of everyday speech and traditional philosophy consists in the belief that ethical issues can be treated as matters of representation, and thus, as being external to ourselves and how we relate to the world.

Certainly, this therapy never ends. Wittgenstein's demand of the philosophers to come to silence does not primarily mean to retreat from positive statements, but by being silent perform a pertinent solidarity towards that which cannot be put in words. According to this interpretation, the resolution of philosophical problems through logical analysis and silence does not mean that they are removed, but rather, that they have found their adequate space and are present in this very way.

\section{Bildung and Ignorance - Some Concluding and Incipient Remarks}

The readings of Plato's Charmides and Wittgenstein's Tractatus present two kindred engagements with the limits of knowledge. In the Charmides, one encounters a different kind of ignorance than how it is usually conceived, i.e. as a contingent gap. By inviting Charmides to examine himself, Socrates points toward that which cannot be formulated in the language of knowledge because it relates to Charmides' own existence. This relation, however, is not at his disposal and this is why ignorance cannot lead to self-contentment but requires a further engagement with the matter of temperance. A bracketing or visitation of the self takes place that enables a criticism regarding Charmides' pretences to know. The experience of ignorance eventually opens the always insecure path of a philosophical and virtuous life.

In Wittgenstein's Tractatus, a clarification of the status that the limits of representation and knowledge have for us is of primary importance. However, how we approach and circumscribe this limit via logical argumentation and thetic statements plays a central role. Both our ignorance of these limits and more importantly of our existence is something hidden by representation. Knowledge of the world, we find out, touches neither the ethical or aesthetic dimensions of our lives, nor our relationship to the world. It is through this failure of representation, a rupture in our mode of engagement with the world, that our existence becomes manifest. For Wittgenstein, this rupture is something that cannot be dealt with in a direct manner. Rather, the reader is led along the path of logical analysis to find out that it is impossible to remain on 
this path. A solidary ${ }^{18}$ silence towards that which cannot be put in words is required in the end.

For both the philosophical approaches presented, here, the limits of knowledge are decisive for the question of human self-determination - the question of Bildung. In both approaches, it is neither positive knowledge nor the availability of knowledge that allows for the essential change of perspective. Rather, the change of perspective comes about in the moment it becomes clear that the limits of knowledge are not external to knowledge, i.e., that they are constitutive for knowledge. Put in different terms, our trust and belief in knowledge might keep us from coming to terms with what temperance is and with what the ethical in general is about. Correspondingly, both the Platonic Socrates as well as Wittgenstein regard their pedagogical undertakings as a practice where the basis of our beliefs, i.e., that which is taken for granted in everyday life and everyday speech, is itself called into question. Socrates, as presented by Plato, and Wittgenstein take their interlocutors to the heart of the matter by putting them on the path of knowledge and showing them how this path fails.

However, there is also a difference between the two readings presented here. Socrates clearly sees the significance of another meeting with Charmides. The dialogue is carried on by envisioning a future even though the future engagements will never provide a satisfactory answer regarding the question of temperance. For the ancient world, in other words, the explicit engagement with the virtues remains a viable path even though it becomes clear that the transcendental ground of knowledge proves itself to be transcendent with respect to our attempts at comprehension. Wittgenstein's Tractatus, by contrast, leads the reader into silence as the ultimate comportment toward the limits of knowledge: It is conceived as a ladder that once climbed must be discarded. Given the „transcendental homelessness (Lukács) of knowledge“ (Gamm 1994: 39, our transl.) in the modern era, this conclusion might not be surprising. As a consequence, Wittgenstein not only refers to the limits of knowledge, but also to the limits of representation in general. ${ }^{19}$ Representation - and this even refers to the most evident natural phenomena - takes

18 This solidarity is reminiscent of Adorno's solidarity with metaphysics in the moment of its downfall.

19 For the later Wittgenstein, the grounding and understanding of knowledge will become a question of practices and usage. Along these lines, the meaning and legitimacy of knowledge will itself become a matter that cannot be determined once and for all, but needs to be seen in a heuristic network of language games and family resemblances. It is here that we arrive at the full meaning of modern contingency, where the authority of knowledge becomes something procedural and temporal. The fabrication of knowledge in relation to social practices is, however, not our theme in the present article. 
shape in view of a liminality that cannot be disclosed from within the sphere of representation.

In our view, it is astounding that in the educational sciences the present discussion surrounding the questions of ignorance and uncertainty is very vivid (cf. e.g. Helsper/ Hörster/ Kade 2003) while at the same time the conceptualization of Bildung is strongly linked to a positively determined understanding of knowledge and competences. In other words, despite the amplification of reality and the inexplorable horizons of referentiality and contextuality, the positive relation of determination between subjectivity, knowledge, and reasoning regarding Bildung remains unaltered (cf. Schäfer 2007). No matter how the development of competences is understood - be it, for example, oriented toward individual actionability, be it the outcome of a self-directed process - in all of these approaches, a strong subject is assumed that has (fallible) knowledge at its disposal. Ignorance and uncertainty decline to an exterior condition in the subject's handling of knowledge (which always remains an object of changing relevance). Bildung is, here, seen as a permanent self-adaptation to the requirements that the subject is thought to be able to identify unambiguously.

In contrast to this widely held understanding, the readings of Plato and Wittgenstein take up a distanced position toward a strong and self-transparent subject. The subject of Bildung is not a subject of knowledge, but, rather, a subject of ignorance (cf. C. Thompson 2005). All attempts to regain a solid referential viewpoint will sooner or later fail ${ }^{20}$ and leave the self in the indeterminable gap between knowledge and its grounds. ${ }^{21}$ Bildung, in this respect, remains heterogeneous to the order of knowledge. Thus, the Charmides and the Tractatus attempt to direct our attention towards the liminality of educational relationships, on the one hand, and to put more effort in the conceptualization of the heterogeneity between Bildung and the order of knowledge, on the other.

The constitutive nature of ignorance that has come to the fore in the presented readings can be interpreted as an important first step in overcoming the interpretation that links ignorance to an over-intellectualized understanding of reflection or the inevitability of a dull narrow-mindedness. It is a future task of educational philosophy and research to substantiate the impossibility of locating the self (or oneself) in processes of education and Bildung, and from

20 This holds true for the Platonic Socrates as well as for the Wittgenstein of the Tractatus.

21 In an article from 1996, Michael Wimmer has thematized „the gift of Bildung“. We believe that Wimmer's thoughts regarding a distancing of the self and an irreducible difference in the realm of knowledge is not incommensurate with the path that we stroke. Cf. also Derrida's thoughts on knowledge and the event (2003). 
here to rethink the positivity of knowledge, its legitimation, and its subjective significance.

\section{Bibliography}

Ballauff, Theodor (2004): Pädagogik als Bildungslehre, Baltmannsweiler: Schneider.

Cavell, Stanley (1999): The Claim of Reason: Wittgenstein, Scepticism, Morality and Tragedy, New York: Oxford University Press.

Conant, James (1997): „Kierkegaard's Postscript and Wittgenstein’s Tractatus: Teaching How to Pass from Disguised to Patent Nonsense." In: Wittgenstein Studien, 4 (2). http://sammelpunkt.philo.at:8080/519/ (Zugriff am 13.1.2008).

Crary, Alice/Read, Rupert (2000): The New Wittgenstein, Milton Park: Routledge.

Derrida, Jacques (2003): Eine gewisse unmögliche Möglichkeit, vom Ereignis zu sprechen, Berlin: Merve.

Diels, Hermann/ Kranz, Walther (1992, Hg.): Die Fragmente der Vorsokratiker. Band 1, Hildesheim: Weidmann.

Dörpinghaus, Andreas (2003): ,,... und wovon man nicht reden kann, darüber muß man schweigen.' Zum Verhältnis von pädagogischer Skepsis und Sprachkritik.“ In: Norbert Meder (Hg.), Zwischen Gleichgültigkeit und Gewissheit. Herkunft und Wege pädagogischer Skepsis, Würzburg: Königshausen \& Neumann, S. 55-70.

Edwards, James C. (1985): Ethics Without Philosophy: Wittgenstein and the Moral Life, Tampa: University Presses of Florida.

Fahrenbach, Helmut (1997): „Grenzen der Sprache und indirekte Mitteilung. Wittgenstein und Kierkegaard über den philosophischen Umgang mit existentiellen (ethischen und religiösen) Fragen." In: Wittgenstein Studien, 4 (2). http://sammelpunkt.philo.at:8080/520/ (Zugriff am 13.11.2007).

Fischer, Wolfgang (1989): Unterwegs zu einer skeptisch-transzendentalkritischen Pädagogik. Ausgewählte Aufsätze 1979-1988, Sankt Augustin: Academia.

Fischer, Wolfgang (1997): Kleine Texte zur Pädagogik der Antike, Baltmannsweiler: Schneider.

Fischer, Wolfgang (2004): Sokrates pädagogisch. Hg. von Jörg Ruhloff und Christian Schönherr, Würzburg: Königshausen \& Neumann.

Foucault, Michel (1993): „,Technologien des Selbst.“ In: Luther Martin/Huck Gutmann / Patrick H. Hutton (Hg.), Technologien des Selbst, Frankfurt/M.: Fischer, S. 24-62. 
Frost, Ursula (1999): „Gespräch als Ort der Bildung und sein Verfall.“ In: Ursula Frost (Hg.), Das Ende der Gesprächskultur? Zur Bedeutung des Gesprächs für den Bildungsprozeß, Münster: Aschendorff, S. 7-18.

Helsper, Werner/ Hörster, Reinhard/ Kade, Jochen (2003, Hg.): Ungewissheit. Pädagogische Felder im Modernisierungsprozess, Weilerswist: Velbrück.

Kant, Immanuel (1990): Kritik der reinen Vernunft, Hamburg: Meiner [zit. $\mathrm{KrV}]$.

Meyer-Drawe, Käte (1998): „Streitfall Autonomie. Aktualität, Geschichte und Systematik einer modernen Selbstbeschreibung von Menschen.“ In: Walter Bauer et. al. (Hg.), Fragen nach dem Menschen in der umstrittenen Moderne. Jahrbuch für Erziehungs- und Bildungsphilosophie 1, Baltmannsweiler: Schneider, S. 31-49.

Penner, Terry (1992): „Socrates and the Early Dialogues.“ In: Richard Kraut (Hg.): The Cambridge Companion to Plato, Cambridge, New York: Cambridge University Press, S. 121-169.

Peperzak, Adriaan T. (1998): „Daß ein Gespräch wir sind.“ In: Bernhard Waldenfels/Iris Därmann (Hg.), Der Anspruch des Anderen. Perspektiven phänomenologischer Ethik, München: Fink, S: 17-34.

Platon (1990): Werke in 8 Bänden. Hg. von Gunther Eigler, Darmstadt: Wissenschaftliche Buchgesellschaft.

Plato (2007): Charmides; or, Temperance. Translated by Benjamin Jowett, o.A.: Dodo Press [zit. Charm.].

Platon (2000): Charmides. Übers. und hg. von Ekkehard Martens. Stuttgart: Reclam [zit. Charm.].

Platzer, Barbara (2007): Sprechen und Lernen. Untersuchungen zum Begriff des Lernens im Anschluß an Ludwig Wittgenstein, Würzburg: Königshausen \& Neumann.

Ramaekers, Stefan (2003): „Wittgenstein and Cavell: reappraising scepticism in educational theory." In: Paul Smeyers/Mark Depaepe (Hg.), Beyond empiricism: on criteria for educational research, Leuven: Leuven University Press, S. 195-206.

Reichenbach, Roland (2007): Philosophie der Bildung und Erziehung, Stuttgart: Kohlhammer.

Ruhloff, Jörg (1999a): „Sokratische Skepsis in der Pädagogik. Eine wissensarchäologische Studie mit Ausblicken auf das Verhältnis von Skepsis und Kritik." In: Dietrich Benner et. al. (Hg.), Bildung und Kritik, Weinheim: Deutscher Studienverlag, S. 11-28.

Ruhloff, Jörg (1999b): „Zum transzendentalkritisch-skeptischen Einsatz der Bildungs- und Erziehungsphilosophie in Deutschland.“ In: Walter Bauer et. al. (Hg.), Globalisierung: Perspektiven - Paradoxien - Verwerfungen. Jahrbuch für Bildungs- und Erziehungsphilosophie 2, Baltmannsweiler: Schneider, S. 177-185. 
Schäfer, Alfred (2005): „Die initiatorische Bedeutung der sokratischen Elenktik." In: Dietrich Benner (Hg.), Erziehung - Bildung - Negativität. 49. Beiheft der Zeitschrift für Pädagogik, Weinheim: Beltz, S. 38-48.

Schäfer, Alfred (2007): Bildung. Ms.

Schäfer, Alfred (2008): Wissen. Projektskizze. Ms.

Schönherr, Christian (2003): Skepsis als Bildung. Skeptisch-transzendentalkritische Pädagogik und die Frage nach ihrer Konstruktivität, Würzburg: Königshausen \& Neumann.

Smeyers, Paul/Marshall, James (1995, Hg.): Philosophy and Education. Accepting Wittgenstein's Challenge, New York: Springer.

Thompson, Christiane (2005): „The Non-Transparency of the Self and the Ethical Value of Bildung." In: Journal of Philosophy of Education 39, S. 519-533.

Thompson, James (2008): Wittgenstein on Phenomenology and Experience: An Investigation of Wittgenstein's ,Middle Period,' University of Bergen Press: Publications of the Wittgenstein Archive.

Weiß, Gabriele (2004): Bildung des Gewissens, Wiesbaden: VS.

Wieland, Wolfgang (1999): Platon und die Formen des Wissens, Göttingen: Vandenhoeck \& Ruprecht.

Wimmer, Michael (1996): „Die Gabe der Bildung.“ In: Jan Masschelein/Michael Wimmer, Alterität Pluralität Gerechtigkeit. Randgänge der Pädagogik, Sankt Augustin: Academia, S. 127-162

Wimmer, Michael (2002): „Pädagogik als Kulturwissenschaft. Programmatische Überlegungen zum Status der Allgemeinen Erziehungswissenschaft.“ In: Lothar Wigger/Ernst Cloer/Jörg Ruhloff/Peter Vogel/Christoph Wulf (Hg.), Forschungsfelder der Allgemeinen Erziehungswissenschaft. Zeitschrift für Erziehungswissenschaft 5, Beiheft 1, Opladen: Leske \& Budrich, S. 109-122.

Wimmer, Michael (2006): Dekonstruktion und Erziehung. Studien zum Pardadoxieproblem in der Pädagogik. Bielefeld: transcript.

Wittgenstein, Ludwig (1969): Notebooks: 1914-1916. Hg. von G. H. von Wright and G. E. M. Anscombe. Übers. von G. E. M. Anscombe, New York: Harper Torchbooks.

Wittgenstein, Ludwig (2000): Philosophical Investigations. Übers. von G. E. M. Anscombe, Toronto: Macmillan.

Wittgenstein, Ludwig (1969): Tractatus Logico-Philosophicus. Übers. von D. F. Pears und B. F. Guinness, London: Routledge \& Kegan Paul [zit. TLP]. Wittgenstein, Ludwig (1971): Prototractatus. Hg. von B. F. McGuinness et al. Übers. von D. F. Pears and B. F. McGuinness, London: Routledge \& Kegan Paul. 